\title{
Comparative vulnerability of Indosylvirana temporalis and Clinotarsus curtipes (Anura: Ranidae) tadpoles to water scorpions: importance of refugia and swimming speed in predator avoidance
}

\author{
Santosh M. Mogali, Bhagyashri A. Shanbhag, and Srinivas K. Saidapur \\ Department of Zoology, Karnatak University, Dharwad-580 003, Karnataka State, India. E-mail: santoshmogali@rediffmail.com.
}

\begin{abstract}
Comparative vulnerability of Indosylvirana temporalis and Clinotarsus curtipes (Anura: Ranidae) tadpoles to water scorpions: importance of refugia and swimming speed in predator avoidance. The comparative vulnerability of two co-existing tadpole species (Indosylvirana temporalis and Clinotarsus curtipes) to their common predator, water scorpions (Laccotrephes sp.; Hemiptera: Nepidae), and the importance of refugia in predator avoidance were studied in the laboratory. In a total of 60 experimental trials, 10 tadpoles each of $I$. temporalis and $C$. curtipes of comparable body sizes were exposed to water scorpions (starved for $48 \mathrm{~h}$ ). Thirty trials included refugia while 30 did not. The results of this study showed that in both the absence and the presence of refugia $C$. curtipes tadpoles fell prey to water scorpions more frequently than I. temporalis tadpoles. A main difference between the two species is the speed of swimming; $V_{\max }$ of $C$. curtipes $(24.73$ $\mathrm{cm} / \mathrm{s})$ tadpoles is lower than that of I. temporalis $(30.78 \mathrm{~cm} / \mathrm{s})$ tadpoles. This is likely to be the reason why more $C$. curtipes tadpoles were preyed upon than were I. temporalis tadpoles. Predation risk of tadpoles of both species was affected significantly by the presence of refuge sites. The vulnerability of both tadpole species was lower where refuge sites were available. The present study clearly shows that I. temporalis tadpoles avoid predation by water scorpions more effectively than do $C$. curtipes tadpoles.
\end{abstract}

Keywords: Defensive behavior, Hemiptera, Laccotrephes sp., Nepidae, predator-prey relationships, refuge sites, tadpoles.

\footnotetext{
Resumo

Vulnerabilidade comparativa dos girinos Indosylvirana temporalis e Clinotarsus curtipes (Anura: Ranidae) aos escorpiões da água: importância de abrigos e da velocidade de natação na evitação de predadores. A vulnerabilidade comparativa de duas espécies de girinos coexistentes (Hylarana temporalis e Clinotarsus curtipes) ao seu predador comum, o escorpião-d'água (Laccotrephes sp.; Hemiptera: Nepidae), e a importância dos abrigos na evitação de predadores foram estudados em laboratório. Em um total de 60 ensaios experimentais, 10 girinos de de cada
}

Received 15 October 2021

Accepted 03 December 2021

Distributed December 2021 
espécie, tamanhos de corpo comparáveis, foram expostos a escorpiões-d'água (mantidos sem alimento por 48 horas). Trinta experimentos incluíram abrigos, enquanto outros 30 não o fizeram. Os resultados deste estudo mostraram que, tanto na ausência como na presença de abrigos, os girinos de C. curtipes foram predados mais frequentemente do que os girinos de I. temporalis. Uma diferença principal entre as duas espécies foi a velocidade de natação; a $V_{\max }$ dos girinos de C. curtipes $(24,73$ $\mathrm{cm} / \mathrm{s}$ ) foi menor que a dos girinos de I. temporalis $(30,78 \mathrm{~cm} / \mathrm{s})$. Provavelmente foi esse o motivo pelo qual mais girinos de $C$. curtipes foram predados em relação I. temporalis. O risco de predação de girinos de ambas as espécies foi significativamente influenciado pela presença de locais de refúgio. A vulnerabilidade de ambas as espécies foi menor onde havia locais de abrigo disponíveis. O presente estudo mostra claramente que os girinos de I. temporalis evitam mais eficazmente a predação por escorpiões-d'água do que os girinos de C. curtipes.

Palavras-chave: comportamento defensivo, girinos, Hemiptera, Laccotrephes sp., locais de abrigo, Nepidae, relações predador-presa.

\section{Introduction}

In nature, predation is a major selective force acting on prey that forces the evolution of strategies for assessment of predation threat and the development of antipredator defense strategies in order to optimize survival and fitness (Lima and Dill 1990). In aquatic environments, tadpoles of most anurans face varying levels of predation threat and therefore evolve a variety of defense strategies. Antipredator strategies of anuran tadpoles observed in earlier studies include increased activity or high swimming speed in order to run away from predators (Hews 1988, Van Buskirk and McCollum 2000), reduction in activity levels to avoid detection (Kiesecker et al. 1996, Schmidt and Amézquita 2001, Saidapur et al. 2009, Mogali et al. 2011, 2012, 2020a), aggregation (Spieler and Linsenmair 1999) and increased use of refuge sites (Stauffer and Semlitsch 1993, Nystrom and Abjornsson 2000, Hossie and Murray 2010, Mogali et al. 2019) depending upon species. Because they exist in aquatic environments, anuran tadpoles mainly use chemical signals to assess predation threats since visual information may be obscured in water that is turbid or densely vegetated (Kiesecker et al. 1996, Mogali 2018).

The tadpoles of Indosylvirana temporalis (Günther, 1864) and Clinotarsus curtipes
(Jerdon, 1853) co-exist along gently flowing streams and in isolated pockets of water along sides of streams during the post-monsoon season in the South-Western Ghats of India (Hiragond and Saidapur 2001, Mogali et al. 2012, 2016). They are mainly bottom dwellers and thrive on detritus and algal matter (Hiragond and Saidapur 2001). Visibility is low in these water bodies due to shadows from vegetation, and the benthic area that is naturally covered by leaf litter and detritus (Mogali et al. 2019). These water bodies are home to several types of predatory invertebrates including water scorpions, Laccotrephes $\mathrm{sp}$. (Hemiptera: Nepidae). Water scorpions are considered ambush/sit-and-wait, non-gap-limited predators with excellent vision. In nature, they are well camouflaged in the vegetation or detritus, and ambush unsuspecting prey including tadpoles of I. temporalis and C. curtipes with a quick grasping action of the forelegs (Mogali et al. 2020b).

Earlier studies from our laboratory show that, under predation threat by water scorpions, the availability of refuge sites minimizes the larval mortality of both predator-naïve and predatorexperienced I. temporalis (Mogali et al. 2019) and $C$. curtipes (unpubl. data). They also show that predator-experienced tadpoles of both species use refuge sites more effectively and survive better than predator-naïve tadpoles.

In natural environments, we noticed that 
tadpoles of both species co-exist and use similar hiding places when needed, hence it is very important to know about the comparative vulnerability of tadpoles to their common predator, water scorpions. Hence, the present study was designed to determine the comparative vulnerability of wild-caught tadpoles (predatorexperienced) of I. temporalis and C. curtipes of comparable body size at early stages of development (Gosner stages 25-27) to free hunting water scorpions both in the presence and the absence of refuge sites. We hypothesized that there should be a difference in the vulnerability between two anuran tadpole species.

\section{Materials and Methods}

Tadpoles of Hylarana temporalis (Gosner stages 27-28; $N=\sim 800)$ and Clinotarsus curtipes (Gosner stage 25; $N=\sim 800$ ) were collected from a stream in the Western Ghats near Anmod village $\left(15.43088^{\circ} \mathrm{N}, 74.37360^{\circ}\right.$ E), Karnataka State, India in November and brought to the laboratory. Tadpoles of each species were placed separately in glass aquaria $(90 \times 30 \times 15 \mathrm{~cm})$ containing $25 \mathrm{~L}$ of aged tap water and used as a stock. Tadpoles of both species are herbivores and were fed boiled spinach to sustain growth and development. The water scorpions (Laccotrephes sp.; predators; $N$ $=70$ ) were collected from the same location that the tadpoles were obtained and were reared individually in plastic tubs $(14 \mathrm{~cm}$ diameter and $7 \mathrm{~cm}$ deep) with $500 \mathrm{~mL}$ of aged tap water to avoid cannibalism. Prior to the commencement of the experiment, predators were daily fed equally with both prey species (3 I. temporalis + 3 C. curtipes tadpoles; Gosner stage 25) for at least four days.

\section{Experiment 1: Comparative Vulnerability of Prey Species}

This experiment was designed to determine the comparative vulnerability of I. temporalis and C. curtipes tadpoles to predatory water scorpions and the importance of refugia in predator avoidance. We carried out a total of sixty experimental trials over a week period. Ten trials were conducted per day, in ten separate experimental tubs each containing one of two treatments. Each trial started at 07:00 AM and ended at 07:00 the next day. In each trial ten tadpoles each of I. temporalis (Gosner stages $27-28 ; 21.12 \pm 0.23 \mathrm{~mm}$ in total length; $5.37 \pm$ $0.14 \mathrm{~mm}$ in width and weight $58.00 \pm 3.42 \mathrm{mg}$; mean $\pm \mathrm{SD}$ across all trials) and $C$. curtipes (Gosner stage $25 ; 21.10 \pm 0.24 \mathrm{~mm}$ in total length; $5.35 \pm 0.16 \mathrm{~mm}$ in width and weight $57.80 \pm 3.50 \mathrm{mg}$; mean $\pm \mathrm{SD}$ ) of comparable body sizes were released in a plastic tub $(32 \mathrm{~cm}$ diameter and $14 \mathrm{~cm}$ deep) containing $3 \mathrm{~L}$ of aged tap water. They were allowed to acclimate for 30 $\min$. Then one water scorpion $(61.50 \pm 3.49 \mathrm{~mm}$ in total length, $10.18 \pm 0.24 \mathrm{~mm}$ in width and weighing $629.0 \pm 13.15 \mathrm{mg}$; mean $\pm \mathrm{SD}$ across all trials) starved for $48 \mathrm{~h}$ was introduced into the tub. After $24 \mathrm{~h}$ the number of surviving $I$. temporalis and C. curtipes tadpoles was recorded to compute the number of tadpoles of each species lost due to predation.

In thirty trials (five per day over six days) the tubs containing the tadpoles and predators provided no refugia for the tadpoles. In a second thirty trials, carried out five per day over the same six days, the tubs contained structural refuges made using water soaked (two days) leaves of Aporosa lindleyana (dry mass $15 \pm 1.6$ $\mathrm{g}$; mean $\pm \mathrm{SD}$ ) chopped into $\sim 1 \mathrm{~cm}^{2}$ pieces. These were spread at the bottom of the testing tubs to serve as shelters/ refuge sites. Predation risk was studied as described above. The test tubs in all trials were washed thoroughly before each trial. Both tadpole species were well fed with boiled spinach before trials. However, during the trial hours they were not provided any food. All experimental trials were carried out at room temperature $\left(25^{\circ} \mathrm{C}\right)$. Relative vulnerability of I. temporalis and C. curtipes tadpoles to predation in each experiment was tested using Mann-Whitney $U$-tests (SPSS software ver. 16.0). 
Experiment 2: Burst Swimming Speed of Prey Tadpoles

The vulnerability of the prey species ( $I$. temporalis and $C$. curtipes tadpoles) to predation by water scorpion differed significantly (Experiment 1). It was thus of interest to know the differences in the swimming speeds between the prey species. To determine $V_{\max }$, a single test tadpole (either I. temporalis or C. curtipes) of comparable body size (see expt. 1) was placed in a plastic tub $(20 \mathrm{~cm}$ diameter and $10 \mathrm{~cm}$ deep) filled with aged tap water to a depth of $2.5 \mathrm{~cm}$ and left undisturbed for $5 \mathrm{~min}$ to adjust to new conditions. A handycam (Sony, DCR-SR300/E) was positioned above the tub to record activity in the entire tub. The handycam was connected to a computer with the Ethovision Video Tracking System (Noldus Information Technology, The Netherlands) to track the movements of the test tadpole. After $5 \mathrm{~min}$ of acclimation, the test tadpole (either I. temporalis or C. curtipes) was chased continuously for $1 \mathrm{~min}$ by prodding the tail base with a delicate wire as described by Van Buskirk and McCollum (2000). The movement of the tadpole was tracked to determine the $V_{\max }$. A total of 25 trials were carried out for both tadpole species with a new test tadpole of each species every time. Both tadpole species were well fed with boiled spinach before trials. The $V_{\max }$ of two tadpole species was compared by Mann-Whitney $U$-test (SPSS software ver. 16.0).

\section{Results}

\section{Experiment 1: Comparative Vulnerability of Prey Species}

Either in the absence or presence of refuge sites significantly higher numbers of $C$. curtipes tadpoles fell prey to water scorpions as compared to I. temporalis tadpoles (Table 1). Predation risk of tadpoles of both species was affected significantly by the presence of refuge sites. The vulnerability of both tadpole species was lower where refuge sites were available (Table 1).

\section{Experiment 2: Burst Swimming Speed of Prey Tadpoles}

There was a significant difference in the swimming speed between tadpoles of the two

Table 1. Number of prey tadpoles (mean \pm SE) of Indosylvirana temporalis and Clinotarsus curtipes consumed by the predator, Laccotrephes sp., in a 24 h trial period ( $N=30$ trials. "Mann-Whitney U-test; ${ }^{*}$ indicates significant difference between two treatments.

\begin{tabular}{lccc}
\hline \multirow{2}{*}{ Treatment } & \multicolumn{2}{c}{ Tadpoles consumed } & U and $\boldsymbol{p}$ values ${ }^{\#}$ \\
\cline { 2 - 3 } & Indosylvirana temporalis & Clinotarsus curtipes & \\
\hline Without refuge sites & $2.60 \pm 0.23$ & $4.03 \pm 0.40$ & $U=268.0, p<0.05^{*}$ \\
With refuge sites & $1.43 \pm 0.21$ & $2.53 \pm 0.27$ & $U=256.0, p<0.05^{*}$ \\
$U$ and $p$ values & $U=229.5, p<0.05^{*}$ & $U=265.5, p<0.05^{*}$ & \\
\hline
\end{tabular}

Table 2. Burst swimming speed $\left(V_{\max }\right.$; mean $\left.\pm \mathrm{SE}\right)$ of Indosylvirana temporalis and Clinotarsus curtipes tadpoles $(\mathrm{N}=$ 25 trials). "Mann-Whitney $U$ test; ${ }^{*}$ indicates significant difference between two species.

\begin{tabular}{lc}
\hline Species & $\boldsymbol{V}_{\max }(\mathbf{c m} / \mathbf{s})$ \\
\hline Indosylvirana temporalis & $30.78 \pm 1.24$ \\
Clinotarsus curtipes & $24.73 \pm 1.01$ \\
$U$ and $p$ values ${ }^{\#}$ & $U=147.50, p<0.05^{*}$ \\
\hline
\end{tabular}


species. The I. temporalis tadpoles exhibited a greater $V_{\max }(30.78 \mathrm{~cm} / \mathrm{s})$ than that of the $C$. curtipes $(24.73 \mathrm{~cm} / \mathrm{s}$ ) tadpoles (Table 2$)$.

\section{Discussion}

In aquatic environments, most prey organisms including larval anurans live under great predation pressure. This results in the evolution of defense means to escape from predation and promote survival (Schmidt and Amézquita 2001, Relyea 2007). The results of this study showed that in both the absence and the presence of refuge sites, $C$. curtipes tadpoles fell prey to water scorpions more easily than I. temporalis tadpoles. A main difference between the two species is the speed of swimming; the $V_{\max }$ of $C$. curtipes tadpoles is lower than that of $I$. temporalis tadpoles. Hence, $C$. curtipes tadpoles are more vulnerable to capture by predators than are I. temporalis tadpoles. Our results conform to those of earlier studies (Van Buskirk and McCollum 2000, Dayton et al. 2005). It is generally believed that refuge sites reduce predation risk (Nystrom and Abjornsson 2000, Mogali et al. 2019). In the present study the vulnerability of both tadpole species was lower where refuge sites were available.

The results of the present study show that $C$. curtipes tadpoles are more vulnerable to predators than those of I. temporalis. The present study on comparative vulnerability of tadpoles of I. temporalis and C. curtipes was conducted only at early larval stages of development (Gosner stages 25-27). The vulnerability of the two species may not be the same throughout the larval period because the tadpoles of I. temporalis complete its larval period within 3-4 months (Hiragond and Saidapur 1999, Saidapur 2001, Mogali et al. 2016) but those of $C$. curtipes grow to larger body size over very long larval periods i.e., from six months to one year (Saidapur 2001). Further studies comparing the species throughout development are therefore needed. The finding of the present study clearly shows that at early stages of development, I. temporalis tadpoles have developed better predator avoidance behavior than that of $C$. curtipes tadpoles.

\section{Acknowledgments}

This study was supported by a grant from the Department of Science and Technology (SP/SO/ AS-38/2009), New Delhi, awarded to BAS and SKS. SMM was supported as a Project Assistant on the project. The study was conducted as per the ethical guidelines of CPCSEA, New Delhi, India (registration no. 639/02/a/CPCSEA).

\section{References}

Dayton, G. H., D. Saenz, K. A. Baum, R. B. Langerhans, and T. J. DeWitt. 2005. Body shape, burst speed and escape behavior of larval anurans. Oikos 111: 582-591.

Hews, D. K. 1988. Alarm response in larval western toads, Bufo boreas: release of larval chemicals by a natural predator and its effect on predator capture efficiency. Animal Behaviour 36: 125-133.

Hiragond, N. C. and S. K. Saidapur. 1999. Description of tadpole Rana temporalis from South India. Current Science 76: 442-444.

Hiragond, N. C. and S. K. Saidapur. 2001. Microhabitat choice of tadpoles of seven anuran species. Current Herpetology 20: 51-60.

Hossie, T. J. and D. L. Murray. 2010. You can't run but you can hide: refuge use in frog tadpoles elicits densitydependent predation by dragonfly larvae. Oecologia 163: 395-404.

Kiesecker, J. M., D. P. Chivers, and A. R. Blaustein. 1996. The use of chemical cues in predator recognition by western toad tadpoles. Animal Behaviour 52: 1237-1245.

Lima, S. L. and L. M. Dill. 1990. Behavioral decisions made under the risk of predation: a review and prospectus. Canadian Journal of Zoology 68: 619-640.

Mogali, S. M. 2018. Predatory cues influence the behavioral responses and metamorphic traits of Polypedates maculatus (Anura: Rhacophoridae). Asian Herpetological Research 9: 199-194.

Mogali, S. M., S. K. Saidapur, and B. A. Shanbhag. 2011. Levels of predation modulate antipredator defense behavior and metamorphic traits in the toad Bufo melanostictus. Journal of Herpetology 45: 428-431. 
Mogali, S. M., S. K. Saidapur, and B. A. Shanbhag. 2012. Tadpoles of the bronze frog (Rana temporalis) assess predation risk before evoking antipredator defense behavior. Journal of Ethology 30: 379-386.

Mogali, S. M., S. K. Saidapur, and B. A. Shanbhag. 2016. Influence of desiccation, predatory cues, and density on metamorphic traits of the bronze frog Hylarana temporalis. Amphibia-Reptilia 37: 199-205.

Mogali, S. M., S. K. Saidapur, and B. A. Shanbhag. 2019. Experience of predacious cues and accessibility to refuge minimize mortality of Hylarana temporalis tadpoles. Acta Herpetologica 14: 15-19.

Mogali, S. M., S. K. Saidapur, and B. A. Shanbhag. 2020a. Behavioral responses of tadpoles of Duttaphrynus melanostictus (Anura: Bufonidae) to cues of starved and fed dragonfly larvae. Phyllomedusa 19: 93-98.

Mogali, S. M., B. A. Shanbhag, and S. K. Saidapur. 2020b. Vulnerability of Hylarana temporalis tadpoles to predation by water scorpions (Laccotrephes, Nepidae). Herpetological Review 51: 699-701.

Nystrom, P. and K. Abjornsson. 2000. Effect of fish chemical cues on interaction between tadpoles and crayfish. Oikos 88: $181-190$.

Relyea, R. A. 2007. Getting out alive: How predators affect the decision to metamorphose. Oecologia 152: 389 400 .
Saidapur, S. K. 2001. Behavioral ecology of anuran tadpoles: the Indian scenario. Proceedings of Indian National Science Academy B67: 311-322.

Saidapur, S. K., D. K. Veeranagoudar, N. C. Hiragond, and B. A. Shanbhag. 2009. Mechanism of predator-prey detection and behavioral responses in some anuran tadpoles. Chemoecology 19: 21-28.

Schmidt, B. R. and A. Amézquita. 2001. Predator-induced behavioral responses: tadpoles of the neotropical frog Phyllomedusa tarsius do not respond to all predators. Herpetological Journal 11: 9-15.

Spieler, M. and K. E. Linsenmair. 1999. Aggregation behaviour of Bufo maculates tadpoles as an antipredator mechanism. Ethology 105: 665-686.

Stauffer, H. and R. D. Semlitsch. 1993. Effects of visual, chemical and tactile cues of fish on the behavioral responses of tadpoles. Animal Behaviour 46: 355-364.

Van Buskirk, J. V. and A. McCollum. 2000. Influence of tail shape on tadpole swimming performance. Journal of Experimental Biology 203: 2449-2458.

Editor: Ross Alford 